\title{
PERFORMANCE COMPARISON BETWEEN FUEL CELL COUPLED WITH GEOTHERMAL SOURCE HEAT PUMP AND GEOTHERMAL SOURCE GAS ENGINE HEAT PUMP SYSTEM FOR GREENHOUSE HEATING: A MATHEMATICAL STUDY
}

\author{
Alexandros Sotirios Anifantis, Simone Pascuzzi, Francesco Santoro \\ University of Bari Aldo Moro, Italy \\ alexandrossotirios.anifantis@uniba.it, simone.pascuzzi@uniba.it, francesco.santoro@uniba.it
}

\begin{abstract}
LPG, diesel and natural gas are generally used for greenhouse conditioning. Alternative technologies should be developed to increase the productivity of the protected environments. Innovative solutions are represented by photovoltaic, geothermal, wind and solar thermal integrated in a stand-alone system in agriculture land. The present paper compares the performances of two renewable energy systems for greenhouse heating based on geothermal and hydrogen technologies. The first integrated system is composed by a photovoltaic array, an electrolyzer, a hydrogen storage tank, a fuel cell and a ground source heat pump connected to a geothermal borehole. The second system, instead, is composed by a photovoltaic array, an electrolyzer, a hydrogen storage tank and a gas engine heat pump connected to a geothermal borehole. In order to compare the two systems, both heat pumps produced the same greenhouse heating power input. The results show a difference between the internal and external greenhouse air temperature from 7 to $15^{\circ} \mathrm{C}$ in winter, considering a deep insulating greenhouse cover material. As regarding the first system, the following energy efficiency has been calculated, photovoltaic arrays $13 \%$, electrolyzer $50 \%$, fuel cell $40 \%$ and the ground source heat pump coefficient of performance $400 \%$. Than the total energy efficiency of the first system is $10.4 \%$. Instead, the overall efficiency of the second system is $11.9 \%$ considering the same performance of the photovoltaic arrays and the electrolyzer of the first system and the ground source gas engine heat pump's primary energy ratio of $181 \%$. The primary energy ratio of the ground source gas engine heat pump seems to be low and not competitive respect to the coefficient of performance of a ground source heat pump, but considering the overall efficiencies of the both systems the performances are reversed. Furthermore, the first system is more complex than the second one.
\end{abstract}

Keywords: greenhouses, geothermal, hydrogen, gas engine.

\section{Introduction}

Greenhouses are essential in those regions with unfavourable environmental temperatures. However, the energy consumption of the greenhouse conditioning systems can overtake the $70 \%$ of the production costs. For these reasons, the use of renewable energy resources for greenhouse heating can be a solution [1]. Furthermore, low enthalpy geothermal sources are becoming usual for greenhouse heating [2-5], especially for economical and installation reasons [6; 7]. In addition, the solar energy usage for greenhouse heating could be an environmental friendly and economically sustainable solution [8]. Unfortunately, the solar energy is non-stable and the electric energy coming out from the PV panels highly depends on the weather conditions. Hydrogen gas from water electrolysis is a vector with high energy density that can be used to storage the electric energy coming from the PV panels [9]. In the paper, the comparison of the energy efficiencies of two stand-alone geothermal and hydrogen systems integrated for greenhouse heating is studied by a mathematical model. The research is focused on two different geothermal energy systems, a geothermal source heat pump (GSHP) and a geothermal source gas engine heat pump (GSGEHP).

\section{Materials and Methods}

The first system is composed by a photovoltaic arrays connected to an electrolyzer, a hydrogen storage tank, a fuel cell and a GSHP (system 1). The second system, like the first one, starts with a PV, hydrogen electrolyzer and storage tank, but instead of the fuel cell and the GSHP a GSGEHP is implemented for greenhouse heating (system 2). The specifications are reported in Tab. 1. The principle behind the operation of the system is that the electric energy coming from the PV provides power for the electrolyzer, then the hydrogen is accumulated in a tank and, during the night, the tank provides hydrogen for the fuel cell coupled with the GSHP or for the GSGEHP. Both power systems have been calculated for supplying the hot water demanded for heating a greenhouse of $468 \mathrm{~m}^{2}$ of area and $983 \mathrm{~m}^{2}$ of cover surface $\left(A_{c f}\right)$. The greenhouse structure is composed by tubular steel. The cover material used is a polyethylene film with a thickness of $200 \mu \mathrm{m}$, in order to increase the isolation propriety of the greenhouse cover film, a double layer with an air inflated gap of four centimetres is 
considered. Then the thermal resistance value (R) of the greenhouse covering system is $0.3 \mathrm{~m}^{2} \cdot{ }^{\circ} \mathrm{C} \cdot \mathrm{W}^{-1}$ [10]. The hot sides condensing temperatures of both heat pumps are about $40-45^{\circ} \mathrm{C}$, while the evaporating temperatures of the cool sides are $7-12^{\circ} \mathrm{C}$.

Table 1

System 1 and System 2 components

\begin{tabular}{|c|c|c|}
\hline Components & $\begin{array}{c}\text { System } 1 \\
\end{array}$ & System 2 \\
\hline PV array & BYD 240P6-30, $356 \mathrm{~kW}$ peak & BYD 240P6-30, $286 \mathrm{~kW}$ peak \\
\hline Electrolyzer & $\begin{array}{c}43 \text { stacks of an AEM electrolyzer } 2.5 \\
\mathrm{~kW}, 0.5 \mathrm{Nm}^{3} \cdot \mathrm{h}^{-1}-\text { Heliocentris }\end{array}$ & $\begin{array}{c}35 \text { stacks of an AEM electrolyzer } 2.5 \\
\mathrm{~kW}, 0.5 \mathrm{Nm}^{3} \cdot \mathrm{h}^{-1}-\text { Heliocentris }\end{array}$ \\
\hline $\mathrm{H}_{2}$ cylinder & 30 bar, $3.6 \mathrm{~m}^{3}$ & $30 \mathrm{bar}, 2.9 \mathrm{~m}^{3}$ \\
\hline Fuel cell & $\begin{array}{l}\text { 6-7 modules of a } 2 \mathrm{~kW} \text { PEM Fuel Cell } \\
\text { (T-2000TM), 24/48 V - ReliON }\end{array}$ & ( \\
\hline Battery & $75 \mathrm{kWh}$ & - \\
\hline $\mathrm{HP}$ & Model NBW $207 \mathrm{H}$, Aermec, $48 \mathrm{kWth}$ & - \\
\hline GEHP & e & $\begin{array}{c}\text { Model AWGP450E1 } 16 \text { HP, Aisin- } \\
\text { Toyota }\end{array}$ \\
\hline $\begin{array}{c}\text { Geothermal } \\
\text { borehole }\end{array}$ & $\begin{array}{l}7 \text { vertical double U-bend ground heat } \\
\text { exchanger, } 120 \text { m deep }\end{array}$ & $\begin{array}{l}6 \text { vertical double U-bend ground heat } \\
\text { exchanger, } 120 \mathrm{~m} \text { deep }\end{array}$ \\
\hline Fan-coil unit & $\begin{array}{l}14 \text { fan-coils of CRC53MV - Carisma. } \\
\text { Heating capacities: } 3.6 \mathrm{~kW} \text {; air flow } \\
\text { rate } 495 \mathrm{~m}^{3} \cdot \mathrm{h}^{-1}\end{array}$ & $\begin{array}{l}14 \text { fan-coils of CRC53MV - Carisma. } \\
\text { Heating capacities: } 3.6 \mathrm{~kW} \text {; air flow } \\
\text { rate } 495 \mathrm{~m}^{3} \cdot \mathrm{h}^{-1}\end{array}$ \\
\hline Greenhouse & $470 \mathrm{~m}^{2}$ & $470 \mathrm{~m}^{2}$ \\
\hline
\end{tabular}

Regarding system 1, starting from the solar energy, the electrolyzer power input is a portion of the PV energy output [11] and it depends on several factors, such as the solar radiation, the performance of the solar cell and the solar radiation usability [12]. Furthermore, the electrolyzer energy efficiency $\eta_{e l}$ is given by the equation [13]:

$$
\eta_{e l}=\left(\delta_{H 2} q_{H 2, e l} L H V_{H 2}\right) / P_{e l},
$$

where $\delta_{H 2}-$ hydrogen density at standard condition, $0.0899 \mathrm{~kg} \cdot \mathrm{Nm}^{-3}$ [11];

$q_{H 2, e l}-$ overall hydrogen production rate, $\mathrm{Nm}^{3} \cdot \mathrm{s}^{-1}$;

$L H V_{H 2}$ - lower heating value of hydrogen, $119.96 \mathrm{MJ} \cdot \mathrm{kg}^{-1}[11]$;

$P_{e l}$ - electrolyzer power input, $\mathrm{W}$.

The energy efficiency of the PEM fuel cell is given by:

$$
\eta_{f c}=P_{f c} /\left(\delta_{H 2} q_{H 2, f c} L H V_{H 2}\right),
$$

where $P_{f c}-$ fuel cell power output, W [11];

$q_{H 2, f c}-$ fuel cell hydrogen consumption rate, $\mathrm{Nm}^{3} \cdot \mathrm{s}^{-1}$.

The COP of the GSHP is given by:

$$
C O P_{-G S H P}=Q_{1 \_G S H P} /\left(Q_{1 \_G S H P}-Q_{2 \_G S H P}\right)=Q_{1 \_G S H P} / L_{-G S H P},
$$

where $Q_{1-G S H P}-$ heating power supplies by the heat pump, W;

$Q_{2 \_G S H P}$ - heating power absorbed from the ground by the heat pump, W;

$L_{-G S H P}$ - electrical power supply to the heat pump, W.

The heat power extracted from the ground $\left(Q_{2}\right)$ is also given by:

$$
Q_{2 \_G S H P}=q_{r} l_{t},
$$

where $q_{r}$-heating exchange rate $[14-16], \mathrm{W} \cdot \mathrm{m}^{-1}$;

$l_{t}-$ total active length of the borehole [11; 17-19], $\mathrm{m}$.

At night, the greenhouse heating power demand can be calculated neglecting the transitory effects and considering the steady state conditions $[20 ; 10]$ :

$$
Q_{1 \_G S H P}=\left[A_{c f} / R\right]\left(f_{W}\right)\left(f_{C}\right)\left(f_{S}\right)\left(T_{i}-T_{a}\right),
$$

where $f_{W}$ - wind factor, 1 ; 
$f_{C}-$ construction type factor, 0.9 ;

$f_{S}-$ system factor, 1 ;

$R$ - thermal resistances of the greenhouse covering material, $0.3 \mathrm{~m}^{2} \cdot \mathrm{C}^{\mathrm{o}} \cdot \mathrm{W}^{-1}$.

Then, the heat transfer coefficient $\mathrm{K}$ is $3 \mathrm{~W} \cdot \mathrm{m}^{-2} \cdot{ }^{\circ} \mathrm{C}^{-1}$.

Regarding system 2 , the equivalent thermal power supplies by the ICE $\left(Q_{g a s}\right)$ is given by [21]:

$$
Q_{\text {gas }}=\delta_{H 2} q_{H 2, \text { gas }} L H V_{H 2} \text {, }
$$

where $q_{H 2, g a s}-$ ICE hydrogen consumption rate, $\mathrm{Nm}^{3} \cdot \mathrm{s}^{-1}$.

The same efficiency is for the ICE powered by natural gas with hydrogen. In steady state conditions and with the optimum air/fuel equivalence ratio the efficiency $\left(\eta_{m}\right)$ can be assumed equal to 0.39 [22]. Then the mechanical power supply to the heat pump by the ICE's shaft of the GSGEHP $\left(L_{-} G S G E H P\right)$ is given by:

$$
L_{-G S G E H P}=\eta_{m} Q_{g a s} .
$$

The return water from the air conditioning system [23] of the GSGEHP firstly enters the condenser to absorb the condenser heat and then goes through the water-to-water heat exchanger and gas to water heat exchanger to recover the engine waste heat. Then the heated water again supplies the air conditioning system for space heating [23]. Therefore, the total heat gained $\left(Q_{1 \_G S G E H P \_T O T}\right)$ is given by [24]:

$$
Q_{1 \_G S G E H P \_T O T}=Q_{1 \_G S G E H P}+Q_{\text {recov }},
$$

where $Q_{1-G S G E H P}-$ heating power supplies by the only heat pump cycle of the GSGEHP, W; $Q_{\text {recov }}$ - engine waste heat recovered from the cylinder jacked and the exhaust gas, W.

Eq. 1, Eq. 3 and Eq. 4 can be used also for system 2 just changing the subscript from "GSHP" to "GSGEHP". Furthermore, the Eq. 5 can be used if instead of $Q_{1_{-G S H P}}$ is considered $Q_{1_{\perp G S G E H P \_T O T}}$.

The PER and the recovery efficiency $\left(\eta_{\text {recov }}\right)$ given by the manufacturer are used to calculate the performance and $Q_{\text {recov }}$ of the gas engine driven heat pumps [23;25]:

$$
\begin{gathered}
Q_{\text {recov }}=\eta_{\text {recov }} Q_{\text {gas }}, \\
P E R=Q_{1_{-G S G E H P} \text { TOT }} / Q_{\text {gas }}=\eta_{m} C O P_{-G S G E H P}+\eta_{\text {recov }},
\end{gathered}
$$

\section{Results and Discussion}

At the experimental site latitude, the solar radiation peak ranged from 0.5 to $1 \mathrm{~kW} \cdot \mathrm{m}^{-2}$. Unfortunately, in winter, the cloudy day influenced the performance of the hydrogen system and the average clearness index can be considered equal to 0.2 [21]. In summer, when the cooling demand is very high, the cycle of the GSHP and the GSGEHP can be inverted, otherwise, natural or dynamic ventilation, operated by the fans, could be enough [26]. Fig.1. shows the power flow diagrams of the systems 1 and 2, in February, the coldest month of the year. In winter, in order to maximize the work time of the electrolyzer, the PV panels peaks $\left(P_{P V}\right)$ should be increased by 3.3 times than the electrolyzer power input $\left(P_{e l}\right)$, then, $\mathrm{P}_{\mathrm{PV}}$ is equal to $356 \mathrm{kWp}$ and $286 \mathrm{kWp}$ for the systems 1 and 2, respectively. Both GSHP and GSGEHP heating systems work during the night for ten hours, while the electrolyzer works only for five hours depending on the weather conditions, for this reason, the hydrogen production rate of the electrolyzer for both systems $\left(q_{H 2, e l \_G S H P}=21.6 \mathrm{Nm}^{3} \cdot \mathrm{h}^{-1}\right.$, $\left.q_{H 2, e l-G S G E H P}=17.4 \mathrm{Nm}^{3} \cdot \mathrm{h}^{-1}\right)$ must be doubled compared to the fuel cell or GSGEHP hydrogen consumption rate $\left(q_{H 2, f c}=10.8 \mathrm{Nm}^{3} \cdot \mathrm{h}^{-1}, q_{H 2, \text { gas }}=8.7 \mathrm{Nm}^{3} \cdot \mathrm{h}^{-1}\right)$. The monthly average electrolyzer electric power inputs $\left(P_{e l}\right)$ of the systems 1 and 2 ranged from 25 to $110 \mathrm{~kW}$ and from 20 to $90 \mathrm{~kW}$, respectively and then the monthly average electrolyzer mass flow outputs ranged from 6 to $20 \mathrm{Nl} \cdot \mathrm{h}^{-1}$ and from 5 to $15 \mathrm{Nl} \cdot \mathrm{h}^{-1}$, respectively (Fig. 2). In summer, $\mathrm{q}_{\mathrm{el}, \mathrm{H} 2}$ increases, but the heating energy demand of the greenhouse decreases.

In winter, during the day, at Mediterranean latitude, the heating systems were turned off and the greenhouse effect was enough to high the greenhouse air temperatures. Then the averages working temperatures of the GSHP and the GSGEHP, and of the greenhouse internal air were analyzed from 18:00 to 8:00. In Fig. 3 the results of one year analysis as monthly average values were showed. The greenhouse thermal power demand $\left(Q_{1_{-} A V}\right)$ is equal to the monthly average heating power supplies by 
the GSHP $\left(Q_{1 \_G S H P}\right)$ and the GSGEHP $\left(Q_{1_{-} G S G E H P \_T O T}\right)$. Instead, the heating power absorbed from the ground by the GSHP $\left(Q_{2_{-} G S H P}\right)$ is smaller than the heat power absorbed by the GSGEHP $\left(Q_{2_{2} G S G E H P}\right)$ thanks to the $Q_{\text {recov }}$.

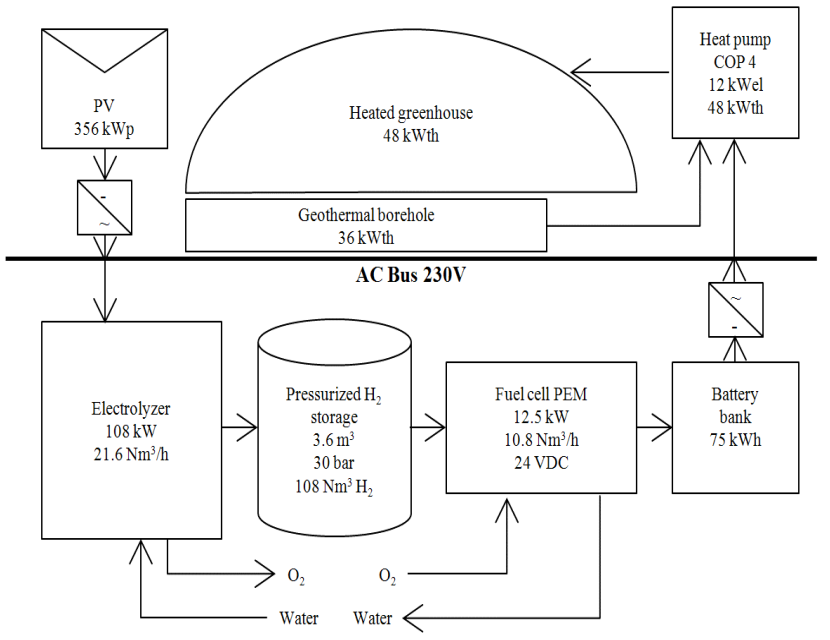

1)

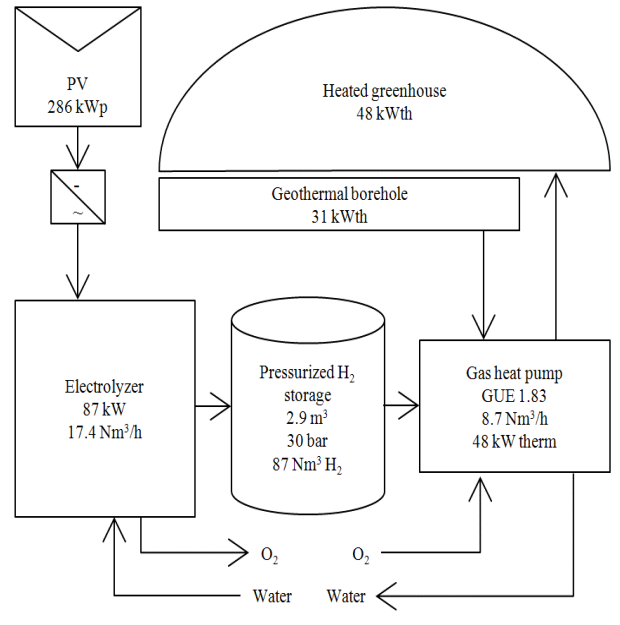

2)

Fig. 1. Comparison between (1) PV, electrolyzer, fuel cell and GSHP system and (2) PV, electrolyzer and GSGHP system in stand-alone applications for greenhouse heating

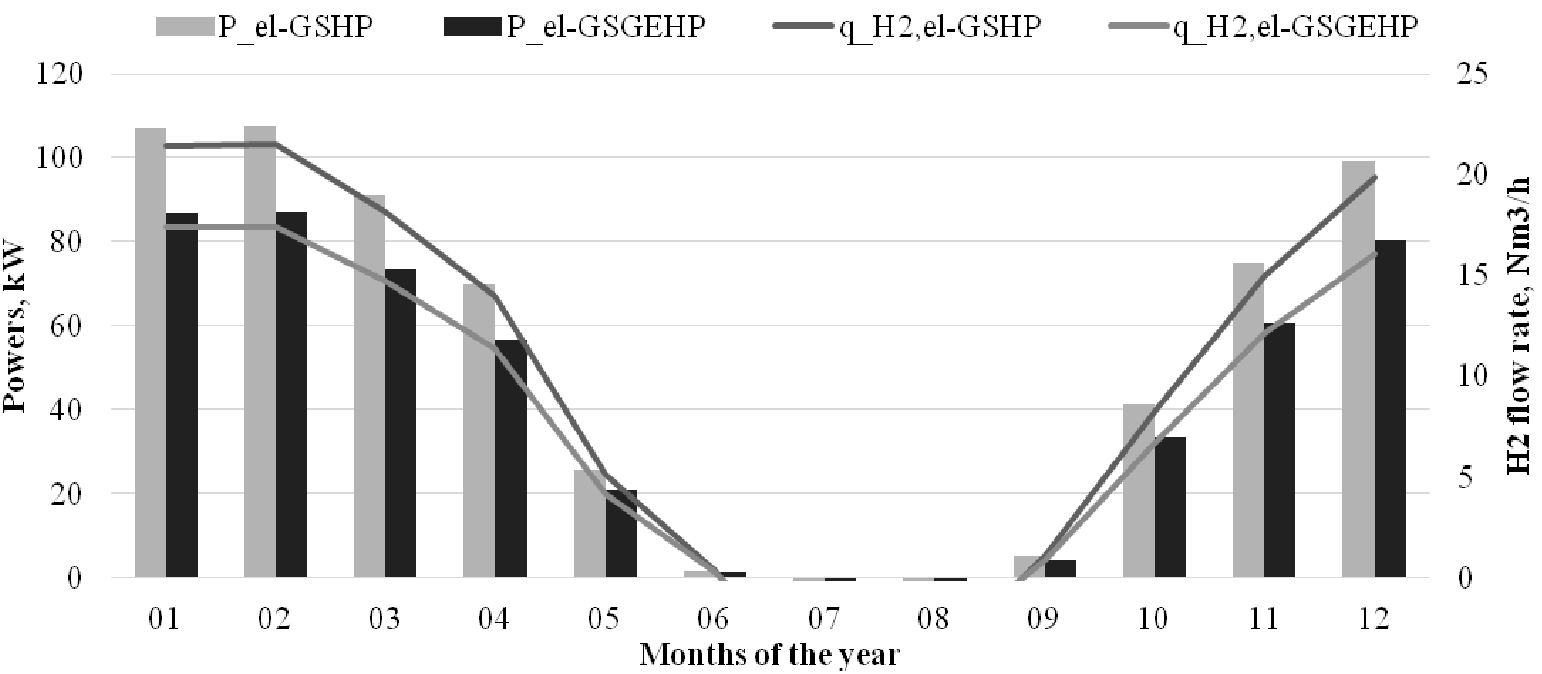

Fig. 2. Monthly average electrolyzer power input and mass flow output for energy supply of GSHP and GSGEHP in 2015

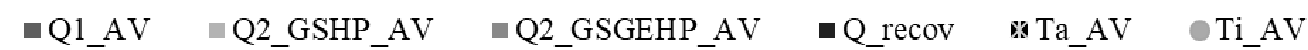

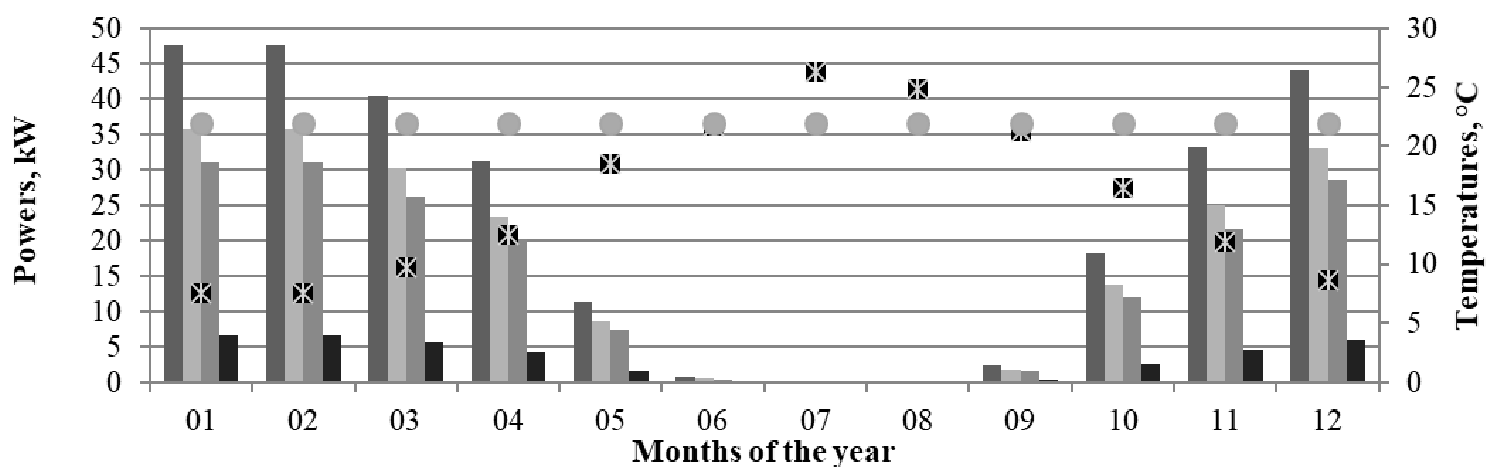

Fig. 3. Monthly average internal and external greenhouse air temperatures, heating power supplies and extracted from ground by GSHP and GSGEHP in 2015 
In February (Fig. 1), $Q_{1_{-} A V}$ is $48 \mathrm{~kW}$ and $Q_{2}$ is $36 \mathrm{~kW}$ and $31 \mathrm{~kW}$ of the systems 1 and 2, respectively. The monthly average heating power supplies by the two systems decreased double from February to April because the average external air temperature $\left(T_{a_{-} A V}\right)$ hardly increased. The year average value of the PER of the GSGEHP was $181 \%$ considering a $\eta_{\mathrm{m}}$ of 0.39 , a COP_GSGEHP of 4 and a $\eta_{\text {recov }}$ of 0.25 . In addition, the $C O P_{-G S H P}$ was considered equal to 4 in order to compare the performances of the two heating systems considering the same operation systems efficiencies. Furthermore, the same thermal power demand of the greenhouse and monthly average external $\left(T_{a_{-} A V}\right)$ and internal $\left(T_{i_{-} A V}\right)$ greenhouse air temperatures were considered for System 1 and System 2. The difference between $T_{a_{-} A V}$ and $T_{i_{-} A V}$ ranged from 15 to $7{ }^{\circ} \mathrm{C}$ from February to April. The heating energies supplied by the two systems were high and the level of temperatures achieved by the internal greenhouse air justifies the investments.

\section{Conclusions}

The present paper calculated the performance efficiencies of GSHP and GSGEHP systems integrated with the hydrogen system fed by PV array for greenhouse heating.

The overall energy efficiency of the first system is $10.4 \%$ considering the efficiency of the PV panels of $13 \%$ the energy efficiency, if the electrolyzer equals to $50 \%$, the efficiency of the fuel cell equals to $40 \%$ and the GSHP's COP of 4, respectively. The overall efficiency of the second system is $11.9 \%$ considering the same energy efficiency of the photovoltaic panels and the electrolyzer of the first system and the GSGEHP's primary energy ratio (PER) of 1.81, respectively. The coefficiency of performance of the GSHP seems to be low and not competitive in respect to the PER of the GSGEHP, but considering the overall efficiencies of both systems the performances are reversed. The PER of the GSHP and GSGEHP highly depend on the coefficient of performance of the thermodynamic Carnot cycle achieved by the heat pump, the ground average annual temperature and the specific heat and exchange rate of the geothermal borehole.

In winter, taking in account a traditional greenhouse cover system, the system 1 and system 2 increase the greenhouse temperature from 7 to $15^{\circ} \mathrm{C}$ in respect to the external air. Furthermore, the first system is more complex than the second one.

\section{Acknowledgments}

Funding source: Fondo di Sviluppo e Coesione 2007-2013-APQ Ricerca Regione Puglia "Programma regionale a sostegno della specializzazione intelligente e della sostenibilità sociale ed ambientale-FutureInResearch".

\section{References}

[1] Sethi V. P., Sumathy, K., Lee, C., Pal, D. S. Thermal modeling aspects of solar greenhouse microclimate control: A review on heating technologies. Solar Energy, vol. 96, 2013, pp. 56-82.

[2] Fujii H., Ohyama K. Application of ground source heat pumps for air conditioning of greenhouses. IEA Heat Pump Centre Newsletter, vol. 27, 2009, pp. 39-42.

[3] Lund J. W., Freeston D. H., Boyd T. L. Direct application of geothermal energy: 2005 worldwide review. Geothermics, vol. 34, 2005, pp. 691-727.

[4] Chai L., Ma C., Ni J.-Q. Performance evaluation of ground source heat pump system for greenhouse heating in northern China. Biosystems Enginnering, vol. 111(1), 2012, pp. 107-117.

[5] Adaro J. A., Galimberti P. D., Lema A. I., Fasulo A., Barral J. R. Geothermal contribution to greenhouse heating. Applied Energy, vol. 64(1-4), 1999, pp. 241-249.

[6] Anifantis A. S., Pascuzzi S., Scarascia Mugnozza G. Geothermal source heat pump performance for a greenhouse heating system: An experimental study. J. Agric. Eng., vol.47, 2016, pp.164-170. http://dx.doi.org/10.4081/jae.2016.544

[7] Benli H., Durmuş A. Evaluation of ground-source heat pump combined latent heat storage system performance in greenhouse heating. Energy and Building, vol. 41(2), 2009, pp. 220-228.

[8] Hassanien R.H.E., Li M., Dong Lin W. Advanced applications of solar energy in agricultural greenhouses. Renew. Sustain. Energy Rev., vol. 54, 2016, pp. 989-1001. 
[9] Pascuzzi S., Anifantis A. S., Blanco I., Scarascia Mugnozza G. Electrolyzer performance analysis of an integrated hydrogen power system for greenhouse heating a case study. Sustainability (Switzerland), vol. 8(7), 2016, pp. 1-15. http://dx.doi.org/10.3390/su8070629

[10] Anon, Greenhouse Heating Requirements, 2003. http://www.cps.gov.on.ca.

[11] Anifantis A. S., Colantoni A., Pascuzzi S. Thermal energy assessment of a small scale photovoltaic, hydrogen and geothermal stand-alone system for greenhouse heating. Renewable Energy, vol. 103, 2017, pp. 115-127. http://dx.doi.org/10.1016/j.renene.2016.11.031

[12] Anifantis A. S. Performance assessment of photovoltaic, ground source heat pump and hydrogen heat generator in a stand-alone systems for greenhouse heating. Chemical Engineering Transactions, vol. 58, 2017, pp. 511-516. http://dx.doi.org/10.3303/CET1758086

[13] Calderóna M., Calderóna A. J., Ramirob A., Gonzálezb J. F., Gonzáleza I. Evaluation of a hybrid photovoltaic-wind system with hydrogen storage performance using exergy analysis. International Journal of Hydrogen Energy, vol. 36, 2011, pp. 5751-5762.

[14] VDI 4640 Blatt 2 standard "Thermische Nutzung Des Untergrundes - Erdgekoppelte Wärmepumpenanlagen”, 2009.

[15] VDI 4640 Blatt 4 standard "Thermische Nutzung Des Untergrundes - Direkte Nutzungen”, 2004.

[16] Sharqawy M. H., Mokheimer E. M., Badr H. M. Effective pipe-to-borehole thermal resistance for vertical ground heat exchangers. Geothermics, vol. 38(2), 2009, pp. 271-277.

[17] Benli H. A performance comparison between a horizontal source and a vertical source heat pump systems for a greenhouse heating in the mild climate Elaziğ, Turkey. Applied Thermal Engineering, vol. 50(1), 2013, pp. 197-206.

[18]Florides G. A., Pouloupatis P. D., Kalogirou S., Messaritis V., Panayides I., Zomeni Z., Partasides G., Lizides A., Sophocleous E., Koutsoumpas K. The geothermal characteristics of the ground and the potential of using ground coupled heat pumps in Cyprus. Energy, vol. 36(8), 2011, pp. 5027-5036.

[19] Ozgener O. Use of solar assisted geothermal heat pump and small wind turbine systems for heating agricultural and residential buildings. Energy, vol. 35(1), 2009, pp. 262-268.

[20] Ozgener O., Hepbasli A. Performance analysis of a solar-assisted ground-source heat pump system for greenhouse heating: An experimental study. Build. Env., vol.40, 2005, pp.1040-1050.

[21] Anifantis A. S., Colantoni A., Pascuzzi S., Santoro F. Photovoltaic and hydrogen plant integrated with a gas heat pump for greenhouse heating: A mathematical study. Sustainability (Switzerland), vol. 10(2), 2018, pp. 1-12. http://dx.doi.org/10.3390/su10020378

[22] Javaheri A., Esfahanian V., Salavati-Zadeh A., Darzi M. Energetic and exergetic analyses of a variable compression ratio spark ignition gas engine. Energ Convers Manage, vol. 88, 2014, pp. 739-748.

[23]Zhang R. R., Lu X. S., Li S. Z., Lin W. S., Gu A. Z. Analysis on the heating performance of a gas engine driven air to water heat pump based on a steady-state model. Energy Conversion and Management, vol. 46(11-12), 2005, pp. 1714-1730.

[24] Yang Z., Wang W.-B., Wu X. Thermal modeling and operating tests for a gas-engine driven heat pump working as a water heater in winter. Energy and Buildings, vol. 58, 2013. pp. 219-226.

[25] TecnoCasa Climatizzazione Sole European Distributor AISIN, Gas Heat Pump (GHP) / Microcogenerator (MCHP), 15/09/2017. www.tecno-casa.com URL.

[26] Trypanagnostopoulos G., Kavga A., Souliotis M., Tripanagnostopoulos Y. Greenhouse performance results for roof installed photovoltaics. Ren. Energy, vol. 111, 2017, pp. 724-731. 